\section{Phosphorylate and conquer}

The mystery of the cell-transformation process and the seemingly simple principles that are involved in cancerous growth began to be unravelled with the study of retroviruses. Research into the function of the protein products that are encoded by oncogenes followed closely on the heels of the discovery of the oncogenes themselves (see Milestones 15 and 17).

In 1978, in an effort to understand the function of the $\operatorname{src}$ oncogene from the avian Rous sarcoma virus (RSV), Michael Bishop and colleagues prepared anti-sera from rabbits that were infected with RSV-induced tumours, to isolate and further characterize the putative product of $s r c$. They found that the anti-sera precipitated a $60-\mathrm{kDa}$

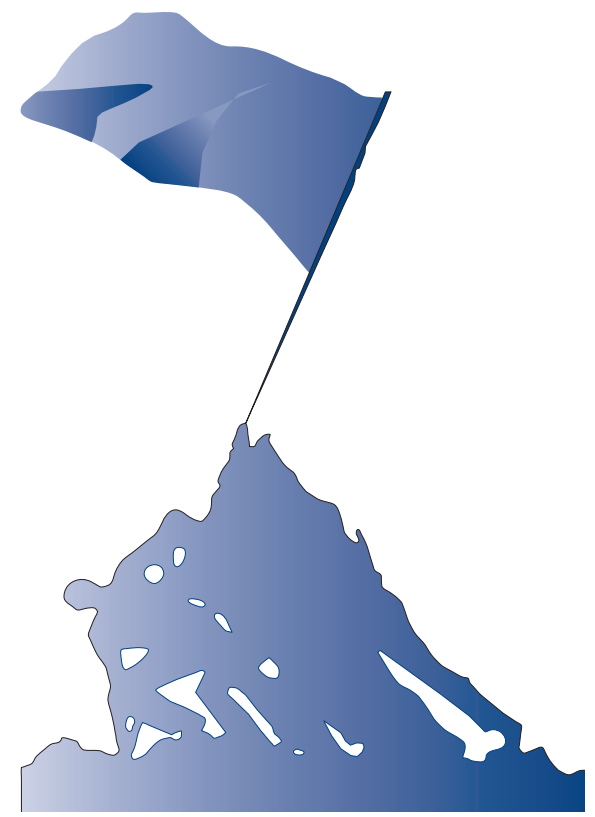

phosphorylated protein product, which they consequently designated as pp60. They showed that phosphorylation of this protein was essential for its function, and that it probably possessed a kinase activity. This study, along with similar findings from the group of Raymond Erikson, indicated that protein phosphorylation might be important in the transformation process.

In late 1979, Tony Hunter and colleagues identified a phosphotyrosine kinase activity in protein immunoprecipitates of the polyoma virus middle $\mathrm{T}$ antigen. Soon thereafter, studies of the Abelson murine leukaemia virus by David Baltimore and colleagues, and of RSV by Hunter and Bartholomew Sefton, identified tyrosinespecific protein kinase activities associated with the product of the Abelson leukaemia viral oncogene $(\mathrm{Abl})$ and $\mathrm{Src}$. Both groups showed that these enzymes were essential for the malignant transformation of cells by the oncogenic proteins. As viral Src was derived from an evolutionarily conserved $c$ $S R C$ cellular proto-oncogene (see Milestone 15), logic dictated that all vertebrate cells must contain at least one protein kinase that phosphorylates tyrosine. Yet, the functional relationship between kinase activity and oncogenesis remained unclear.

Work published by the Stanley Cohen laboratory a few months later, using cell membranes isolated from epidermal growth factor (EGF)-responsive carcinoma cells, provided further insights. They found that activation of the EGF receptor (EGFR)-protein kinase complex resulted in protein phosphorylation, mainly on tyrosine residues. The association of both virusinduced and EGF-induced cell growth with the activation of protein kinases specific for tyrosine was certainly intriguing, and indicated a functional relationship between oncoprotein activity and receptor signalling.

Importantly, shortly thereafter in 1983, Mike Waterfield and colleagues, and Harry Antoniades and colleagues identified the putative transforming protein of simian sarcoma virus as platelet-derived growth factor (PDGF). In addition, in 1984, Mike Waterfield, Yossi Schlessinger and colleagues reported that v-erb $B$ from the avian erythroblastosis virus encodes a similar protein to EGFR. These three papers, along with those identifying the cellular Ras oncogenes (see Milestone 17), showed that the oncogenes found in retroviruses encode components of the normal growthregulatory machinery of the cell.

Many other oncogenes were shown to encode proteins that bound to these kinases as upstream modulators or downstream signal transducers. Not only was it now apparent that tumours might arise owing to the de-regulation of these kinase-mediated signalling pathways, but the possibility of therapeutic intervention was also evident. The outcome of much of this early work has been the development of therapeutic agents (see Milestone 24) that target the mutated oncogenes.

Ekat Kritikou, Locum Associate Editor, Nature Reviews Molecular Cell Biology References and links

ORIGINAL RESEARCH PAPERS Levinson, A. D., Oppermann, H., Levintow, L., Varmus, H. E. \& Bishop, J. M. Evidence that the transforming gene of avian sarcoma virus encodes a protein kinase associated with a phosphoprotein. Cell 15, 561-572 (1978) | Collett, M. S. \& Erikson, R. L. Protein kinase activity associated with the avian sarcoma virus src gene product. Proc. Natt Acad. Sci. USA 75, 2021-2024 (1978) | Eckhart, W. Hutchinson, M. A. \& Hunter, T. An activity phosphorylating tyrosine in polyoma $\mathrm{T}$ antigen immunoprecipitates. Cel/ 18, 925-933 (1979) | Witte, O. N., Dasgupta, A. \& Baltimore, D. Abelson murine leukaemia virus protein is phosphorylated in vitro to form phosphotyrosine. Nature 283, 826-831 (1980) | Hunter, T. \& Sefton, B. M. Transforming gene product of Rous sarcoma virus phosphorylates tyrosine. Proc. Natl Acad. Sci. USA 77, 1311-1315 (1980) | Ushiro, H. \& Cohen, S. Identification of phosphotyrosine as a product of epidermal growth factor-activated protein kinase in A-431 cell membranes. J. Biol. Chem. 255, 8363-8365 (1980) | Waterfield, M. D. et al. Platelet-derived growth factor is structurally related to the putative transforming protein p28sis of simian sarcoma virus. Nature 304, 35-39 (1983) | Doolittle, R. F. et al. Simian sarcoma virus onc gene, $v$-sis, is derived from the gene (or genes) encoding a platelet-derived growth factor. Science $\mathbf{2 2 1}$, 275-277 (1983) | Downward, J. et al. Close similarity of epidermal growth factor receptor and $\mathrm{v}$-erb-B oncogene protein sequences. Nature 307, 521-527 (1984)

FURTHER READING Collett, M. S. et al. A normal cell protein similar in structure and function to the avian sarcoma virus transforming gene product. Proc. Natl Acad. Sci. USA 76, 3159-3163 (1979)
URLs

src

http://www.ncbi.nlm.nih.gov/entrez/query.fcgi?db=gene\&cmd=R etrieve\&dopt=full_report\&list_uids=1491925

pp60

http://www.ncbi.nlm.nih.gov/entrez/viewer.fcgi?db=protein\&val

$=40796163$

polyoma virus middle $\mathrm{T}$ antigen

http://www.ncbi.nlm.nih.gov/entrez/viewer.fcgi? $\mathrm{db}=$ protein\&val $=555285$

\section{EGFR}

http://www.ncbi.nlm.nih.gov/entrez/viewer.fcgi?db=protein\&val $=8815559$

\section{PDGF}

http://www.ncbi.nlm.nih.gov/entrez/viewer.fcgi?db=protein\&val

\section{$=338209$}

